\title{
TRUCK LEASING UNDER THE MOTOR CARRIER ACT: THE OWNER-OPERATOR AND THE ICC
}

The Motor Carrier Act ${ }^{1}$ makes it unlawful to have a motor vehicle engaged in interstate commerce without a license or permit issued by the Interstate Commerce Commission. ${ }^{2}$ The act divides motor carriers into three classes: common, contract and private. ${ }^{3}$ The first two constitute carriage for hire and are therefore subject to rather extensive economic regulation, ${ }^{4}$ as well as licensing requirements. Private carriage, however, is subject only to safety regulations deemed necessary by the Commission. 5

1 Interstate and foreign motor carrier traffic is regulated by the Motor Carrier Act, 49 Stat. 543 (1935), 49 U.S.C. $\$ \$ 301-27$ (1958), enacted as an amendment to the Interstate Commerce Act, 24 Stat. 379 (1887), 49 U.S.C. $\$ \S 1-1542$ (1958). For background and legislative history of the act see, George, Federal Motor Carrier Act of 1935, 21 CoRNELL. L.Q. 249 (1936); ICC, Coordination of Motor Transportation, 182 I.C.C. 263 (1932).

249 Stat. 552 (1935), as amended, 49 U.S.C. § 303(c) (1958): "Except as provided . . no person shall engage in any for-hire transportation business by motor vehicle, in interstate or foreign commerce . . . unless there is in force with respect to such person a certificate or a permit issued by the Commission authorizing such transportation. ..."

354 Stat. 920 (1940), as amended, 49 U.S.C. § 303(a)(14) (1958): "The term "common carrier'... means any person which holds itself out to the general public to engage in the transportation by motor vehicle in interstate or foreign commerce of passengers or property ... for compensation, whether over regular or irregular routes, except transportation by motor vehicle by an express company. ..."

71 Stat. 411 (1957), 49 U.S.C. $\S 303(a)(15)$ (1958): "The term 'contract carrier . . 'means any person which engages in transportation by motor vehicle of passengers or property in interstate or foreign commerce, for compensation ... under continuing contracts with one person or a limited number of persons either (a) for the furnishing of transportation services through the assignment of motor vehicles for a continuing period of time to the exclusive use of each person served or (b) for the furnishing of transportation services designed to meet the distinct need of each individual customer."

49 Stat. 545 (1935), 49 U.S.C. § 303(a)(17) (1958): "The term "private carrier . . ' means any person not included in the terms 'common carrier by motor vehicle' or 'contract carrier by motor vehicle,' who or which transports in interstate or foreign commerce by motor vehicle property of which such person is the owner, lessee, or bailee, when such transportation is for the purpose of sale, lease, rent, or bailment, or in furtherance of any commercial enterprise."

For an excellent study of the distinction between common carriers and contract carriers and their regulation under the Motor Carrier Act, see Comment, National Transportation Policy and the Regulation of Motor Carriers, 71 YALE L.J. 307 (1961). For the Supreme Court's resolution of the problems giving rise to that study, see ICC v. J-T Transp. Co., 368 U.S. 81 (1961).

4 The rates, fares and charges of common carriers are regulated by 49 Stat. 558 (1935), as amended, 49 U.S.C. $\$ 316(1958)$. Rate schedules for contract carriers are subject to Commission approval. 49 Stat. 561 (1935), as amended, 49 U.S.C. \$ 318 (1958).

5 Under the act private carriers were to be subject to safety regulations only if the Commission thought such regulation necessary, 49 Stat. 546(1935), 49 U.S.C. § 304(a)(3) (1958). Such a need was found in 1940. See ICC, Carrier Safety Regulations-Private Carriers, 23 M.C.C. 1 (1940). 
As a result of these regulatory differences, the Commission is frequently required to determine whether a given transportation arrangement is for-hire or private carriage. The problem of distinguishing between these two types of carriage is complicated by the statutory definition of private carriers, which defines that class negatively by reference to the other categories. This negative definition invites an ad hoc determination of whether the operation in question is contract or common carriage. ${ }^{6}$ In order to make this determination the Commission has developed standards that must be met before the transportation is considered private. The inability to differentiate "carriage for-hire" from "private carriage," even with these standards, has encouraged increasing amounts of illegal traffic 7 and aroused governmental concern over the effect of such unregulated traffic on the regulated industry.

Two practices make up the largest share of unlawful transportation: (1) "buy and sell" arrangements used by private and exempt carriers to alleviate the financial burden of "dead-heading"; 8 and (2) "shipper lease of truck and

6 See private carrier definition, supra note 3.

7 Hearings on Surface Transportation-Scope of Authority of ICC, Before a Subcommittee of the U.S. Senate Committee on Interstate and Foreign Commerce, (Statement of George P. Baker, President, Transp. Ass'n of America and Professor of Transportation, Harvard Graduate School of Business), 85th Cong., 1st Sess, at 245 (1957): "Since 1946, the ICCregulated carriers have steadily been losing about 1 percent each year of the total intercity freight volume to their non-ICC regulated competitors, the vast majority of which are private and exempt for-hire carriers. In other words, in 1946, these ICC-regulated carriers handled 82 percent of the total traffic, and last year they handled only 72 percent of it."; ICC, Gray AREA OF TRANSPORTATION ORERATIONS 13 (1960): "The total ton-mileage of unauthorized motor trucking operations estimated by the Commission's field offices is in the neighborhood of 11.2 billion ton-miles a year, or about 4.5 percent of total intercity ton-miles of for-hire and private trucking reported by the Commission in its Seventy-Third Annual Report to the Congress."

8 One of the primary handicaps of private transportation is that the shipper is often required to send outbound shipments to destinations where no return haul of raw materials can be obtained. This return trip without cargo is known as "dead-heading." Since private carriers are permitted by the statute to carry "property of which such person is the owner" shippers attempted to circumvent regulation by purporting to "buy" property at their outbound destinations and "sell" it upon returning home. This type of transportation often resulted from a prior agreement with the eventual purchaser, with the profit involved for the shipper corresponding quite closely to the actual cost of transportation. The Commission detected such subterfuges and subjected them to regulation by means of the "primary business test": the transportation was for-hire unless it was a natural part of the shipper's primary business. Congoleum-Nairn, Inc., 2 M.C.C. 237, 240 (1937). Most difficulties have arisen in businesses where the majority of capital and primary service performed are closely related to the transportation of the goods. In these areas the courts have held that if there is a "risk of profit or loss involved," rather than mere compensation for transportation, then the transportation is bona-fide private carriage. A. W. Stickle \& Co., 128 F.2d 155 (10th Cir.), cert. denied, 317 U.S. 650 (1942); Taylor v. ICC, 209 F.2d 353, 358 (9th Cir. 1953) cert. denied, 347 U.S. 952 (1954). At the present the leading case for the interpretation of the standard is, Brooks Transp. Co., v. United States, 93 F. Supp. 517 (E.D.Va. 1950), aff'd mem., 340 U.S. 925 (1951). Congress incorporated the Commission-developed test into the Motor Carrier Act in 1958, 71 Stat. 411 (1957), as amended, 72 Stat. 574 (1958), 49 U.S.C. $\$ 303$ (c) (1958): "[N]or shall any person engaged in any other business enterprise transport property by motor vehicle in interstate or foreign commerce for business purposes 
driver"9 operations utilized by private shippers to obtain transportation at relatively fixed costs without large amounts of equipment investment. The "buy and sell" arrangements were substantially checked by congressional adoption of the Commission's "primary business" standard,10 and the Commission may have been aided in its efforts to control illegal leasing arrangements by the recent decision of the Supreme Court in United States v. Drum.11 In that case the Court upheld an ICC decision that a lease arrangement, whereby the lessee "hired" the lessor to drive the truck, was for-hire carriage.

The purpose of this comment is to evaluate the Drum decision in light of past Commission and court standards, the national transportation policy and the economic realities of owner-operator leasing arrangements. Before considering Drum, however, a brief description of truck-leasing arrangements, their history and prior treatment by the ICC will be useful.

I.

Truck leasing by shippers began in the nineteen thirties and has increased each year. Its rise has coincided with increases in the initial and maintenance costs of equipment.12 The exclusive lease of vehicles without drivers was excluded from regulation under the Motor Carrier Act.13 Difficulties arose, however, when the lessor performed some service, other than mere equipment rental, for the lessee. As lessor participation in the actual transportation increased, the Commission had to decide when the resulting operation shifted from private carriage on the part of the lessee to transportation for-hire rendered by the lessor. The number of cases in which the Commission has had to make this determination is legion. 14

unless such transportation is within the scope, and in furtherance, of a primary business enterprise ...." See O'Brien, Twenty-Five Years of Federal Motor Carrier Licensing-The Private Versus For-Hire Carrier Problem, 35 N.Y.U.L. REv. 1150, 1158-68 (1960).

9 This is now the most common form of illegal operation. ICC, note 7, supra at 6-7. For other forms of illegal activity, see $i d$. at 7-10. For additional information on the leasing of vehicles and the problems of regulation, see Marks, Is a Lessor of Motor Vehicles a Contract Carrier, 39 Ky. L.J. 338 (1950); Mathews, Truck Leasing by Shippers and the Problem of the Dangling Instrumentalities, 27 ICC PRAC. J. 370 (1960); O'Brien, supra note 8, at $1168-79$.

10 See supra note 8.

11368 U.S. 370 (1962).

12 Harper, Economic Regulation of the Motor Trucking Industry by the States 25 (1959). In many instances the depreciation schedules for owned vehicles do not reflect the needs of the industry. Companies cannot afford to drive their vehicles for extended periods of time. By leasing vehicles shippers may deduct the lease payments as a business expense from gross income, and still drive modern up-to-date equipment. In addition, leasing eliminates many of the bookkeeping and management problems involved in transportation. See Rollins, Trend to Fleet Leasing, 32 HaRv. Bus. REv. (No. 4) 108 (1954).

13 Cross Country Truck Rentals, Inc., 86 M.C.C. 417, 423 (1961); John J. Casale, Inc., 44 M.C.C. 45, 57 (1944); U-Drive-It Co., 23 M.C.C. 799, 800 (1940).

14 G \& W Transfer Co., 89 M.C.C. 251 (1962); United Retail Merchants' Stores, Inc., 89 M.C.C. 183 (1962); Center America Corp., 88 M.C.C. 740 (1962); Huffman, 88 M.C.C. 437 
Three early cases, H.B. Church Service Co., Columbia Terminals, and Edward Allen Carrol, 15 were instrumental in the formulation of the "dominance and control" standard that has been applied in the majority of ICC decisions. The Commission in Church set forth the proposition that "essentially the issue is who has the right to control, direct and dominate the performance of the services" 16 and that this question is to be decided in the "light of all the facts and circumstances surrounding the transactions. . . . No one element of such facts and circumstances is itself conclusive."17 The standard conceptualized in Church has been repeatedly applied by the Commission.

In its case-by-case consideration of various arrangements the ICC has identified a number of factors that help determine whether the lessor or the shipper dominates the transportation.18 In making its decisions, the Commission has considered which party: pays for the cost of fuel and other operating expenses; maintains and garages the vehicle; makes the necessary safety inspections; bears the risk of loss in case of accident; provides the necessary public liability and property damage insurance; 19 gives the drivers their instructions; pays the driver's salary and deducts income and social security taxes; receives the driver's medical reports; and ensures the compliance of drivers with Commission safety regulations. These factors may be divided into two general groups: Those indicating control over the vehicle and those indicating control over the driver. Unless these two main instrumentalities were exclusively supervised by the shipper the operation was considered for-hire carriage on the part of the lessor. ${ }^{20}$ As a result, most of the

(1961); John J. Casale, Inc., 86 M.C.C. 657 (1961); Cross Country Truck Rentals, Inc., 86 M.C.C. 417 (1961); Driver's \& Personnel, Inc., 86 M.C.C. 157 (1961); Garrett, 83 M.C.C. 795 (1960); Lumber Haulers, Inc., 82 M.C.C. 373 (1960); Cummings Truck Lease, Inc., 81 M.C.C. 283 (1959); Oklahoma Furniture Mfg. Co., 79 M.C.C. 403 (1959); Rittenhouse, 78 M.C.C. 389 (1958); Pacific Diesel Rental Co., 78 M.C.C. 161 (1958); Driver Service, Inc., 77 M.C.C. 243 (1958); R.N.G. Auto Renters, Inc., 73 M.C.C. 665 (1957); Equipment Rental, Inc., 71 M.C.C. 311 (1957). For some of the earlier cases dealing with the same subject matter see O'Brien, supra note 8, at $1168 \mathrm{n} .78$.

15 H.B. Church Service Co., 27 M.C.C. 191 (1940); Columbia Terminals Co., 18 M.C.C. 662 (1939); Edward Allen Carrol, 1 M.C.C. 788 (1937).

16 H.B. Church Service Co., supra note 15, at 195-96.

17 Id. at 196.

18 See Mathews, supra note 9, at 376.

19 The concept of control is tied closely to the concept of responsibility toward the public. The law is not prone to hold one responsible for an operation he does not really control. See Franceshino v. Mack, 174 Pa. Super. 518, 102 A.2d 217 (1954). Responsibility to the public through insurance would seem to be a good indication of who was controlling the transportation. But see Pacific Diesel Rental Co., 78 M.C.C. 161, 172 (1958): "In the last analysis a shipper's assumption of any of a carrier's responsibility to the public, in this day when such responsibilities readily can be passed on to insurers, is little more nor less than a rate adjustment."

20 Pacific Diesel Rental Co., 78 M.C.C. 161, 173 (1958); Huffman, 88 M.C.C. 437,440 (1961). 
litigation before the Commission has involved the permissible relationships that may exist between lessor, driver and lessee. 21

The importance of the driver-lessor relationship in such determinations is illustrated by the Commission's findings in C.E. Hall \& Sons, Teaming Corp., and Scott Bros.22 In each case the lessor provided similar services for all lessees, including payment for fuel, operating expenses and maintenance, but leased some of the vehicles with drivers and some without. In each proceeding the operation conducted with drivers furnished by the lessor was found to be carriage for-hire while that conducted with the shipper's own drivers was found to be private carriage.

\section{II.}

The controversy involved in Drum began in August, 1957, when the Interstate Commerce Commission initiated an investigation ${ }^{23}$ to determine whether owner-operators of tractor-trailer units leased to an Oklahoma furniture manufacturer were transporting property in interstate commerce without proper authority from the Commission. ${ }^{24}$ The lessee company, prior to 1952 , had conducted its transportation operations in company vehicles using salaried drivers. Fraudulent use of credit cards by the employees led to the adoption of the lease arrangements. ${ }^{25}$ In 1956 the Arkansas Supreme Court held that transportation of the company's property by owner-operators over Arkansas roads was transportation for-hire under the applicable state statutes. ${ }^{26}$ After this decision the leases were changed to the form that was in effect at the time of the ICC investigation.

21 The courts look at the whole transaction to determine the true relationships of the parties. B \& C Truck Leasing, Inc., v. ICC, 283 F.2d 163, 164-65 (10th Cir. 1960); Georgia Truck Leasing, Inc., v. ICC, 123 F.2d 210, 212 (5th Cir. 1941). It is not the form of the lease that will be controlling, but the actual understanding and conduct of the parties. G. \& W. Transfer Co., 89 M.C.C. 251, 253 (1962); Center America Corp., 88 M.C.C. 740, 742 (1962); Huffman, 88 M.C.C. 437, 441 (1961); D. L. Wartena, 44 M.C.C. 131, 145 (1944).

22 Teaming Corp., 33 M.C.C. 461, 463 (1942); Scott Bros., 32 M.C.C. 253, 255 (1942); C.E. Hail. \& Sons, Inc., 24 M.C.C. 33, 37 (1940). See also Consolidated Trucking, Inc., 41 M.C.C. 737, 738-39 (1943); Columbia Terminals Co., 18 M.C.C. 662, 665-66 (1939).

23 Such investigations are provided for under 49 Stat. 547 (1935), 49 U.S.C. $\S 304$ (c) (1958): "Upon complaint to the Commission by any person, State board, organization, or body politic, or upon its own initiative without complaint, the Commission may investigate whether any motor carrier or broker has failed to comply with any provision of this chapter, or with any requirement established pursuant thereto."

24 Prospective common carriers obtain a certificate if they prove their services will "be required by the present or future public convenience and necessity . . . " 49 Stat. 551 (1935), 49 U.S.C. $\$ 307$ (a) (1958). Contract carriers must prove their operations "consistent with the public interest and the national transportation policy . . . " 49 Stat. 552 (1935), 49 U.S.C. $\& 309$ (b) (1958).

25 For more detail on the company's transportation operations, see Oklahoma Furniture Mfg. Co., 79 M.C.C. 403, 404-06 (1959).

26 Robinson v. Woodward, 227 Ark. 102, 296 S.W.2d 672 (1956), cert. denied, 353 U.S. 988 (1957). 
Under the agreement 27 the owner paid all operating costs and bore the risk of any loss to his equipment through depreciation, accident, fire or theft. The lessee furniture company agreed to provide a qualified company employee as driver, maintain the equipment in compliance with state and federal safety regulations, provide property damage and liability insurance covering the operations of the motor vehicle, and pay a weekly rental fee based on mileage driven. The lessee reserved the right to direct and control the operation. The agreement was to remain in force for one year but could be cancelled by either party upon thirty days notice.

The lessee also entered into union contracts as employer of certain of the owner-operators. Salary rates under that contract, which applied to all drivers whether union members or not, were based on miles driven. The contract exempted the owner-operators from minimum wage and hour guarantees given other employees of the company. The practice, then, was to have the owners drive their own equipment and to ensure, if possible, that each driver received approximately the same driving time.

With one commissioner dissenting, division 1 of the ICC found that the owner-operators were "in substance," engaged in the business of interstate transportation of property on the public highways for-hire as contract carrier by motor vehicle . ..."28 and ordered them to cease and desist. The owners brought suit 29 in the district court to have that order set aside. 30 The three judge court ${ }^{31}$ concluded that the findings of the Commission were not supported by substantial evidence and granted the requested relief. On appeal the Supreme Court reversed, with two Justices concurring in a separate opinion and two dissenting. 32

27 The lease provisions are set out in Drum v. United States, 193 F. Supp. 275, 277 (W.D. Okl. 1960); and Oklahoma Furniture Mfg. Co., 79 M.C.C. 403, 404-06 (1959).

$28 \mathrm{Id}$. at 416.

2928 U.S.C. $\$ 1336$ (1958): "Except as otherwise provided by Act of Congress, the district courts shall have jurisdiction of any civil action to enforce, enjoin, set aside, annul or suspend, in whole or in part, any order of the Interstate Commerce Commission."

30 Drum v. United States, 193 F. Supp. 275 (W.D. Ok1. 1960).

3128 U.S.C. $\$ 2325$ (1958): “An interlocutory or permanent injunction restraining the enforcement, operation or execution, in whole or in part, or any order of the Interstate Commerce Commission shall not be granted unless the application therefor is heard and determined by a district court of three judges under section 2284 of this title." Decisions of district courts so constituted are directly appealable to the Supreme Court. 28 U.S.C. $\$ 1253$ (1958).

32 United States v. Drum, 368 U.S. 370 (1962). Mr. Justice Douglas agreed with the majority that the Commission acted within its authority but felt that the case was a "marginal one on which commissioners as well as judges might differ." Id. at 386 (Douglas and Black, J.J. concurring). Mr. Justice Harlan in a strong dissent felt the majority decision was "inconsistent with the uniform course of agency and court decisions, and ... contrary to the regulatory plan embodied in the Motor Carrier Act. ..." The Commission's action amounted "in effect to an exercise of power which it does not possess." Id. at 387 (Harlan and Whittaker J.J. dissenting). 
Owner-operator arrangements like those in the Drum case have presented difficult questions under the "control and dominance" standard previously used by the Commission. As was said in Church:

In cases ... [of] ... [the] lease of equipment with drivers by a carrier ... the presumption arises that the transportation is performed ... for-hire $\ldots$ and as such is subject to regulation. This presumption will ... yield to a showing that the shipper has the exclusive right and privilege of directing and controlling the transportation service, as for example if the equipment were operated by the shipper's employee. ${ }^{33}$

The facts necessary to overcome this presumption when drivers have leased and subsequently operated their own equipment have never clearly been defined. ${ }^{34}$ While the presumption was usually rebutted by showing that the driver was an employee of the lessee, 35 the Commission in the Drum litigation found the owner-operators were engaged in transportation for-hire

even ... [though] each owner-operator should be considered a bonafide employee of the company with respect to his driving duties ... his own service as a driver cannot be considered to take from him and give to the company such control as would overcome the presumption stated in the Church case.... There is present whenever the owner-operator drives his own equipment the right and power of the lessor to defeat any supposed control that the shipper-lessee might believe exists. ${ }^{36}$

Commissioner Webb, in dissent, and the district court felt this reasoning on the part of the majority meant "that no owner-operator [could] be em-

33 H.B. Church Truck Service Co., 27 M.C.C. 191, 196 (1940).

${ }^{34}$ The ICC seems to indicate in its brief that such a relationship could be private carriage but gives no indication of the terms necessary for such a lease. Brief for Appellant (ICC), p. 16, United States v. Drum, 368 U.S. 370 (1962).

35 The presumption is not overcome by the mere fact that the contract provides that the drivers are the employees of the shipper and that the lessor exercises no control over them. Huffman, 88 M.C.C. 437, 440 (1961); Motor Haulage Co., 46 M.C.C. 106, 118 (1947). The employment must be bona fide and the statement that the driver is the "employee" of the shipper during a one-way trip-lease arrangement is not sufficient to overcome the presumption. Cross Country Truck Rentals, Inc., 86 M.C.C. 417, 426 (1961). Various factors are considered important in determining whether or not the shipper is truly the driver's employer, e.g., whether or not the shipper: Pays the driver's wages, $c f$. Columbia Terminals Co., 18 M.C.C. 662 (1939); deducts social security and federal income taxes, cf. Motor Haulage Co., 46 M.C.C. 107, 118 (1946); John J. Casale, Inc., 44 M.C.C. 45, 53 (1944); retains driver's logs and medical certificates, $c f$. Watson Mfg. Co., 51 M.C.C. 223, 224 (1949); bargains with a union over conditions of employment, $c f$. R.N.G. Commercial Auto Renters, Inc., 73 M.C.C. 665,670 (1957); reserves the right to hire and fire cf. John J. Casale, Inc., 49 M.C.C. 15, 22 (1948). Compare Driver Service, Inc., 77 M.C.C. 243, 246 (1958). However, even when the shipper has assumed all the responsibilities of the employer of the driver, if the driver has vital economic relationships with the lessor or is directly dependent on the lessor for employment the presumption is not overcome. G \& W Transfer Co., 89 M.C.C. 251, 254 (1962); Pacific Diesel Rental Co., 78 M.C.C. 161, 173-74 (1958).

${ }^{36}$ Oklahoma Furniture Mfg. Co., 79 M.C.C. 403, 411 (1959). Compare Pacific Diesel, supra note 35, at 174 . 
ployed by a common carrier, a contract carrier, or by a private carrier, if he rents and drives his own equipment unless ... he holds appropriate authority from the Commission." 37 The district court also criticized the reasoning of the Commission on the question of owner-operator control. ${ }^{38}$ The court saw little difference between the control exercised by the lessee over ordinary employee-drivers and that exercised over employee-owner-operators. 39

But the court's view is open to question in some situations. If an ordinary employee misappropriates a vehicle for his own use he may be subjected to criminal prosecution, while the same activity by an owner-operator would merely constitute contractual breach. In addition, the owner-operator retains the capacity to affect the long term transportation operations of the lessee by exercising his option to terminate the lease. This option to terminate also has the effect of binding together the equipment lease and the employment of the driver in a way that militates against the power of the employer to discharge the owner-operator as driver, a power necessary in order to exercise complete and effective control. In any given situation, however, these differences between owner-operators and employees may be insignificant, and conduct of the owner-operators as well as surrounding circumstances should be considered in determining how much weight need be given them.

The present reasoning of the Commission would seem to preclude any arrangement that would allow the owner-operators to drive their own equipment. 40 This seems to be a harsh result since many of these owner-operators are single vehicle owners with heavy investment in their equipment. ${ }^{41}$ The ing).

37 Oklahoma Furniture Mfg. Co., supra note 36, at 417 (Commissioner Webb, dissent-

38 Drum v. United States, 193 F. Supp. 275, 282 (W.D. Okl. 1960).

39 Ibid.

40 The Commission in its decision did not consider Watson Mfg. Co., 51 M.C.C. 223 (1949), a case with a factual situation quite similar to Drum. The Watson company, a manufacturer of furniture, leased a tractor-trailer unit on a yearly basis with compensation based on mileage and hired the owners under a separate contract as drivers for the leased equipment. Drivers were paid on a miles-driven basis. The Commission found that "there is no question but that the applicant-lessee controls the tractor-trailer unit." Id. at 226. The Commission may have felt the Watson decision not applicable in the Drum situation because there was no evidence that the owner-operator could terminate the lease before one year had elapsed. In other words, the two instrumentalities were completely separate and both were under the control of the company. In Van Meter v. Public Utilities Comm'n, 165 Ohio St. 391, 135 N.E.2d 848 (1956), the state supreme court ruled that a driver-owner, a bona fide employee of the lessee (stipulated), was not engaged in a transportation service. The decision was based on the master-servant relationship, the court reasoning that if the employer was not engaged in transportation for-hire then neither was the employee. A contrary decision was reached by the Supreme Court of Arkansas applying the control doctrine used in the federal courts. Public Service Comm'n v. Lloyd A. Fry Roofing Co. 219 Ark. 553, 244 S.W.2d 147, aff' d, 344 U.S. 157 (1952). For other state decisions see also, Haden v. Rhodes, 271 Ala. 344, 123 So. 2d 916 (1960); State v. Ingalls, 106 So. $2 d 570$ (Fla. App. 1958); Oregon v. O.K. Transfer Co., 215 Ore. 8, 330 P.2d 510 (1958).

41 Oklahoma Furniture Mfg. Co., 79 M.C.C. 403, 419 (1959) (Commissioner Webb, dissenting): "This possible administrative nightmare is considerably less important than the 
Commission was no doubt motivated by the fact that collectively these single owner-operators account for the largest portion of unregulated activity. In appraising the Commission's position, the threat that the owner-operator's activities pose to the regulated carriers must be weighed against the consequences of extending regulation. The Commission's decision may obligate shippers either to purchase their own equipment or pay the higher rates of the regulated carriers, passing these additional costs on to the consumers. For the owner-operators, who may lack capital to compete with the regulated carriers, the result may be to force them into some other occupation.

\section{III.}

In the principal case the district court found the shipper in "exclusive dominance and control" of the operation, 42 and this finding was not appealed to the Supreme Court.43 The Court recognized that the question of who controls and dominates "had been the focus of the Commission's efforts to delineate verbally the permissible area of non-licensed transportation . . . ."44 but went on to say "if the [district] court intended to hold that the Commission is confined to the 'control' test, we think it clearly in error . . . ." 45 The Court reasoned that "a... private carrier who hires the instrumentalities of transportation ... must-if he is not to utilize a licensed carrier-assume in significant measure the characteristic burdens of the transportation business." 46

As a consequence of Drum, a lease arrangement entered into in good faith and satisfying the verbalized standard formerly sufficient to classify it as private carriage, can still be considered by the Court and Commission to be carriage for-hire. 47 The majority of the Court felt that, the Commission had always taken account of factors that "transcend any narrow concept of physical direction of the details of the operation; and [that] it has always been

unwitting, but nevertheless devastating blow which this report delivers to the property rights of numerous small entrepreneurs, as no doubt the tractors of many of the owneroperators involved in this proceeding were purchased at considerable financial sacrifice. ... I cannot impose upon respondents here and others in a similar position what appears to me to be a legally unsupportable sentence of economic excommunication."

42 Drum v. United States, 193 F. Supp. 275, 281 (W.D. Okl. 1960).

43 Brief for Appellant (ICC) p. 17 n.8, United States v. Drum, 368 U.S. 370 (1962).

44 United States v. Drum, supra note 42, at 382.

$45 \mathrm{Yd}$. at 385.

46 Id. at 375.

${ }^{47}$ Schultz Transit, Inc., v. United States, 208 F. Supp. 537 (D. Minn. 1962), illustrates the effect that the Drum decision may have on subsequent lease arrangements. The district court had previously determined the company's operations to be private carriage, ICC v. Schultz Transit, Inc., 207 F. Supp. 749 (D. Minn. 1957), but on the strength of the change in the applicable law brought about by the Drum decision the court held that it was not estopped from ruling that the same transportation operations were now carriage for-hire Schultz Transit, Inc., v. United States, supra at 541. Compare John J. Casale, Inc., v. United States, 208 F. Supp. 55 (S.D.N.Y. 1962) (decision supported by quoting at length from the Drum decision). 
apparent that the vesting of such physical 'control' ... would not in itself suffice to render the transportation private . . . ."48

However, the early Commission decisions, more often than not, resorted to the Church doctrine of physical control over performance without a clear indication of the non-physical factors considered. 49 When such factors were mentioned it was evident the case was decided on the question of whether or not the shipper actually had exclusive control over the driver. 50 There was little indication that any standard other than "control over the instrumentalities" was being used.

The federal courts, however, have indicated that other standards might be used, framing the question in terms of the number of "services rendered" 51 and the extent to which these services are necessary to the transportation operation. Whether or not the service taken as a whole was for compensation has been considered important, 52 as has the question of whether or not the shipper was obtaining transportation at a definite fixed cost.53 In recent proceedings the Commission seems to have followed the lead of the courts as it appeared to move away from the single "control and dominance" test. It has articulated the difference between transportation for-hire and private carriage in terms of over-all "substance" rather than in terms of "control" alone. In Pacific Diesel Rental Co., the Commission asked: "Are any persons here, in substance, engaged in the business of interstate or foreign transportation of property on the public highways for-hire?"54 Whereas the "control" standard looked to the role of the shipper alone, the "substance" standard is also concerned with the functions performed by the lessor. This approach was used by the Commission in the Drum decision 55 and received the sanction of the Supreme Court:

The test of substance with which the Commission supplemented its "control" inquiry in this case thus betokens no heedless departure from the beaten track of administrative decision which might occasion a judicial

48 United States v. Drum, 368 U.S. 370, 383 (1962).

49 See, e.g., Karzen, 31 M.C.C. 613, 614-15 (1942); P.B. Mutrie Motor Transp., Inc., 32 M.C.C. 555,561 (1942).

50 See cases cited note 22 supra.

51 United States v. La Tuff Transfer Service, 95 F. Supp. 375, 380 (D. Minn. 1950): "The decisive question to be determined is how much service, if any, in addition to the vehicle alone, may be rendered by the owner-lessor before the borderline between renting and leasing a truck for private carriage is crossed . . . ." See also ICC v. Werner, 106 F. Supp. 497, 500 (E.D. Ill. 1951); ICC v. F \& F Truck Leasing Co., 78 F. Supp. 13, 19 (D. Minn. 1948).

52 United States v. La Tuff Transfer Service, supra note 51, at 380-81; cf. ICC v. Jamestown Sterling Corp., 64 F. Supp. 121, 122 (W.D.N.Y. 1945). But cf., Brooks Transp. Co. v. United States, 93 F. Supp. 517, 524 (E.D. Va. 1950).

53 ICC v. Isner, 92 F. Supp. 582, 587 (E.D. Mich. 1950).

5478 M.C.C. 161, 172 (1958). (Emphasis added.)

ss Oklahoma Furniture Mfg. Co., 79 M.C.C. 403, 410 (1959). 
curb upon the exercise of administrative discretion. ... The Commission allowably dealt with this novel situation as an integral and unique problem in judgment, rather than simply as an exercise in counting commonplaces. ${ }^{56}$

Though administrative agencies often use standards enunciated in prior cases as precedent in deciding current cases, this does not, and should not, preclude a change when the standard no longer serves the intended purpose. The courts have indicated that they will not necessarily alter their standard of review because an agency has seen fit to change "administrative case-made" standards. 57 This should be particularly true in lease cases such as Drum since there is an indication that the "control" concept was only a prima facie condition that had to be satisfied and was not intended to be the sole test, although it was decisive in the vast majority of cases. This change in standard was probably deemed necessary with respect to truck leases, since the physical control test became less meaningful and more difficult to apply as the lease arrangements became more intricate. 58

Though the "substance" rule may be adequate in determining the relationship between the parties in some cases, it offers little guidance to parties desiring to enter into a lawful lease agreement.

It is not enough to condemn subterfuges and castigate those acting in "bad faith." The shipper entering into a motor vehicle lease is entitled to know with clarity and precision what he may do and what he may not do and the Bar of the Commission is entitled to clear rules of law upon which to base their advice to clients. 59

56 United States v. Drum, 368 U.S. 370,384 (1962). Since the Drum decision the Commission has used the substance test more freely. See, e.g., Center America Corp., 88 M.C.C. 740, 743 (1962) (quoting the Drum case and using the same economic criteria); John J. Casale, Inc., 86 M.C.C. 657, 664 (1961) (operation found to be for-hire carriage even though lessee had physical control). But the control and dominance test has not been completely abrogated. See, e.g., G \& W Transfer Co., 89 M.C.C. 251, 253 (1962); United Retail Merchants Stores, Inc., 89 M.C.C. 183, 186 (1962). Of particular interest is the way the Commission has used the "substance" test to bring the automobile drive-away services under regulation. See Service Associates, Inc., 89 M.C.C. 33 (1962), where an association bringing together persons desiring to have automobiles driven to the West Coast with persons desiring to drive, was held to be engaged in transportation for-hire: "[R]espondent has removed many of those features from its business which tend to indicate responsibility and control over the involved movements ... [but] the respondent still clearly holds itself out to the public to transport automobiles in interstate commerce ...." Id. at 36. See also Spencer, 88 M.C.C. 243 (1961); Studna, 88 M.C.C. 52 (1961).

57 The Court has upheld a change in "formula" by an administrative agency even though the statute has been re-enacted without change by Congress. NLRB v. Seven-Up Bottling Co., 344 U.S. 344, 350-51 (1953). For a discussion of the effect of re-enactment on administrative decisions, see 1 Davis, Admintstrattve Law Treatise 331-38 (1958). See generally R. J. Davis, The Doctrine of Precedent as Applied to Administrative Decisions, 59 W. VA. L. REv. 111, 124-42 (1957).

58 See, e.g., Allen v. United States, 187 F. Supp. 625 (S.D. Fla. 1960); Cross Country Truck Rentals, Inc., 86 M.C.C. 417 (1961); Driver Service, Inc., 77 M.C.C. 243 (1958).

59 Mathews, supra note 9, at 387. 
Indeed, the scope of the "substance" rule may invite disputes. In Drum, for example, Mr. Justice Harlan dissented, "not because the Commission has supplemented its earlier test of 'control' with one of 'substance,' but because the application of the very test that is now urged persuades me that this was ... private carriage...."60 Similarly, the district court found, inter alia, that "both the form and the substance ... point to the fact that what is involved here is private carriage." 61 Two members of the Commission had found, however, that the owner-operators were "in substance, engaged in the business of interstate transportation." 62

The Supreme Court and the Commission recognized the generality of the substance test and attempted to articulate the relevant considerations. The Court held that to be classified as a private carrier the shipper must assume in significant measure the characteristic burdens of the trucking industry. They considered the bearing of financial risks as a necessary burden of private carriage and observed that when such risks are shifted to the lessor it is evidence that the transportation is for-hire. In Drum three such financial risks were identified by the Court as having been shifted to the owner-operators: (1) The risk of premature loss of the large capital investment in the vehicles; (2) the risk of increase in variable operating costs such as fuel and repair expenses; and (3) the risk of non-utilization of equipment. 63

The transfer of the first financial risk to the lessor does not seem to warrant a finding that the carriage is for-hire, since capital investment and risk of loss are born by the lessor in almost all equipment rentals. Similarly, operating costs are borne by the lessor in many lease arrangements without the transportation being for-hire. ${ }^{64}$ The risk of non-utilization would seem, therefore, to have been the decisive factor determining the classification of the carrier. The largest single non-utilization risk in private carriage is that of "dead-heading," of having non-productive "back-haul." This was, however, admittedly borne by the lessee in the Drum operations. 65

The risk of non-utilization referred to by the Court derived from the lack of an obligation on the part of the company to guarantee any amount of transportation: "The owner-operators received neither rental payments nor wages when their tractors were not used and they did not drive."66 The dissenting Justices felt that "if the record revealed that these drivers really risked having

60 United States v. Drum, 368 U.S. 370, 396 (1962) (Harlan, J., dissenting).

61 Drum v. United States, 193 F. Supp. 275, 281 (1960).

62 Oklahoma Furniture Mfg. Co., 79 M.C.C. 403, 414 (1959).

63 United States v. Drum, 368 U.S. 370, 379-80 (1962).

${ }^{64}$ See cases cited note 22 supra.

65 United States v. Drum, 368 U.S. 370,380 (1962) (company carried the risk of nonproductive back-haul).

66 Ibid. 
no work at all . . . over any period of time, there might be room for argument that they were, in fact, independent contractors."67 They felt, however, that since the practice assured that the owner-operators received approximately the same remuneration as salaried employees, non-utilization was not a significant factor. This view seems tenable. It could, however, be argued that should the transportation demands of the industry fluctuate because of strikes, inability to obtain raw material or a declining demand for the shipper's products, the owner-operators rather than the lessee bear the resulting loss. But even here there would be no real threat to lessors, for should such events occur they could protect themselves by executing their options to terminate.

In the final analysis, there seems to be no greater shift of financial risks in the Drum operation than that which occurs when a shipper hires drivers from a driver service and pays them on a mileage basis while leasing the equipment from an unconnected lessor. Operations of this type have been held to be private carriage on the part of the shipper.68

\section{IV.}

The Commission is obligated to administer the Motor Carrier Act consistently with the national transportation policy as declared by Congress. 69 One of the objectives of that policy is to "recognize and preserve the inherent advantages of each"70 mode of transportation. It is apparent that the Commission in the Drum case considered the lease arrangements, not only in the light of certain standards or tests that were to delineate private from for-hire carriage, but also in the context of the effect of such unregulated transportation operations on the regulated industry. The Commission believed that classifying the transportation performed by the owner-operators as private carriage on the part of the lessee "would open the door to unfair

67 Id. at 394 (Harlan, J., dissenting).

68 See, e.g., Cummings Truck Lease, Inc., 81 M.C.C. 283 (1959).

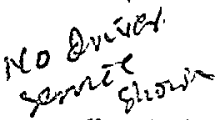

${ }^{69}$ National Transportation Policy, 54 Stat. 899 (1940), 49 U.S.C. preceding $\$ \$ 1,301$, 901, 1001 (1958): "It is hereby declared to be the national transportation policy of the Congress to provide for fair and impartial regulation of all modes of transportation subject to the provisions of this act... so administered as to recognize and preserve the inherent advantages of each; to promote safe, adequate, economical, and efficient service and foster sound economic conditions ... all to the end of developing, coordinating, and preserving a national transportation system ... adequate to meet the needs of the commerce... of the Postal Service, and of the national defense. All of the provisions of this act... shall be administered and enforced with a view to carrying out the above declaration of policy."

The "national transportation policy" is the standard used to measure the Commission's administration of the act. American Trucking Ass'n v. United States, 364 U.S. 1, $6(1960)$; Schaffer Transp. Co. v. United States, 355 U.S. 83, 88 (1957). For the discretion given the Commission in its administration of the act, see ICC v. Parker, 326 U.S. 60, 73 (1945); cf. Palmer Lines, Inc., v. United'States, 179 F. Supp. 629, 634 (D. Mass. 1959).

70 See note 69 supra. 
and destructive competitive practices contrary to the national transportation policy declared by Congress."71

It is conceded that the Commission is more suited than the courts to determine the extent to which the "burdens of private carriage" may be divested without tending to destroy competing modes of transportation, but it is submitted that the Commission should reconsider the economic effects of its decision. In passing on applications for contract-carrier permits under the Motor Carrier Act, the Commission is instructed to take into consideration "the effect which granting the permit would have upon the services of the protesting carriers and the effect which denying the permit would have upon the applicant and/or shipper. . . ."72 Although the provision quoted does not refer to proceedings such as those in Drum, the standards considered there would seem appropriate in a Drum context. This is particularly true where the matter under consideration involves a lease made in good faith and presenting a borderline case under the act.

There wàs no evidence in the Drum case that contract or common carriers were being harmed by the activities of the owner-operators. ${ }^{73}$ In this respect it is significant that the regulated carriers did not file their customary intervention in the Commission proceedings. ${ }^{74}$ Of similar relevance was the evidence that the regulated carriers, because of the nature of the transportation, 75 would not or could not provide adequate service. It is difficult to see how the unregulated owner-operator arrangement, if allowed to continue, would have been "destructive of competition" or otherwise harmful to the regulated carriers. The Commission has faced analogous problems in regulating railroad acquisition and control of motor carrier lines. The prevailing doctrine strongly favors restriction on motor carrier subsidiaries of railroads, but the courts and Commission have agreed "that the public interest may sometimes be promoted by not imposing such limitations."76 Illustrative are cases where the trucking service is not adequately performed.77 It would seem that this reasoning is applicable to situations similar to Drum where inadequate transportation by regulated carriers might be shown.

Another admonition of the national transportation policy is to "promote safe, adequate, economical, and efficient service and foster sound economic

71 Oklahoma Furniture Mfg. Co., 79 M.C.C. 403, 414 (1959). The Supreme Court also considered the effect of the operations on the regulated industry. United States v. Drum, 368 U.S. 370, 375 (1962).

7249 Stat. 553 (1935), as amended, 49 U.S.C. $\$ 309(\mathrm{~b})$ (1958).

${ }^{73}$ See Brief for Appellees, p. 3, United States v. Drum, 368 U.S. 370 (1962).

74 Ibid.

75 ICC, GRAy Area of Transportation Operattons 68-69 (1960).

${ }^{76}$ American Trucking Ass'n v. United States, 364 U.S. 1, 11 (1960).

77 See, e.g., American Trucking Ass'n v. United States, 355 U.S. 141, 153 (1957). 
conditions... ."78. Though the trucking industry in the nineteen thirties was unable to function properly without regulation, 79 it has been suggested that present regulation is excessive. ${ }^{80}$ The cost-structure of the industry is such that there is relatively easy market entry and exit, thus enabling the industry to respond more readily to the demands of the nation's economy than a monopolistic one. 81 Complete withdrawal of economic regulation is unlikely and probably undesirable in view of the declared objective of preserving common carriers at a level of diversity and efficiency necessary to meet defense needs. ${ }^{82}$ Careful consideration should be given, however, to the need for economic controls in situations where the regulation will result in substantially less economic utilization of transportation resources:

There is a general and growing realization that less improvement has been made in distribution than in production of goods and that much of the remaining margin for the improvement of the Nation's economic efficiency lies in the area of distribution. Transportation is the largest single element within that area. And the rate of our economic progress is quite as capable of being slowed by an increase in the cost of transportation relative to other goods and services as it is by the shortage of transportation capacity or a shortfall in the quality of service. 83

Unless the protection of savings to shippers would seriously harm the public interest, the economies obtained through leasing arrangements such as those in Drum are surely worth preserving. "The Nation requires policies which will encourage maximum efficiency in the performance of the transportation function." 84 and until the unregulated traffic is shown to have a seriously adverse effect upon the economics of the industry, the restriction of such "borderline" carriage would seem undesirable.

${ }^{78}$ See note 69 supra. (Emphasis added.)

79 See HAarper, ECONOMIC Regulation OF MOTOR TRUCKING INDUSTRY 28 (1959); ICC, Coordination of Motor Transportation, 182 I.C.C. 263 (1932).

80 Hudson \& Constantin, Motor Transporation 537-38 (1958); Pegrum, Public Regulation of Business 583 (1959); Williams \& Bluestone, Rationale of Federal Transportation Policy (Appendix to Federal Transportation Policy and Program, U.S. Dept. of Commerce) 1-31 (1960).

81 Pegrum, op. cit. supra note 80, at 529-32.

82 National Transportation Policy, note 69 supra; see Hearings Before a Subcommittee of the Committee on Armed Services, House of Representatives-Adequacy of Transportation Systems in Support of the National Defense Effort in Event of Mobilization, 86th Cong., 1st Sess. XVIII-XX (1959) (Conclusions and Recommendations).

83 Williams \& BLUESTONE, op. cit. supra note 80, at 3.

${ }^{84}$ Id. at 2. 